\title{
Positive Affirmation In Education Of Youth Characters In The Millennal Era
}

\author{
Ulfa Amalia \\ Department Guidance and Counseling, Yogyakarta University of Technology \\ e-mail: ulfaamalia.psi@uty.ac.id
}

\begin{abstract}
The fundamental problem in the current 4.0 industrial revolution era is related to character education in adolescents in facing challenges and changes in a very rapid era. The high need to depend on the internet that is very high changes the pattern of social interaction in the real world switching through social media. The development of this era would not only have a negative impact but also bring positive change, but the mental readiness and strength of adolescent characters really need to be formed through positive affirmations which are actually very easy to do but are often ignored because they are lulled by pseudo exposure on social media. This article reviews the importance of habituation with positive affirmations which basically gives an influence on mind to hypnotize oneself through positive words or sentences so that if it is done regularly and continuously, it will be able to bring big changes to the teenagers mindset who tend to be irrational, to be rational. The transition will certainly provide positive energy to the character of adolescents, which is manifested by the ability to be wise in using technology in the present and the future.
\end{abstract}

\section{Keywords: Positive Affirmation, Character Education, Youth, Millennial Era}

\begin{abstract}
Abstrak: Persoalan fundamental pada era revolusi industri 4.0 saat ini terkait pendidikan karakter pada remaja dalam menghadapi tantangan dan perubahan era yang sangat cepat. Ketergantungan pada internet yang sangat tinggi merubah pola interaksi sosial dalam dunia nyata beralih melalui media sosial. Perkembangan era ini tentu bukan hanya berdampak negatif tetapi juga membawa perubahan positif, namun kesiapan mental dan kekuatan karakter remaja sangat perlu dibentuk melalui afirmasi positif yang sebenarnya dengan sangat mudah dapat dilakukan namun seringkali diabaikan karena terlena dengan paparan semu dimedia sosial. Artikel ini mengulas tentang pentingnya habituasi dengan Afirmasi positif, yang pada dasarnya memberikan pengaruh pada alam bawah sadar untuk menghipnosis diri melalui kata-kata atau kalimat positif sehingga jika dilakukan terus menerus dan berkesinambungan akan dapat membawa perubahan besar pada pola pikir remaja yang cenderung irrasional menjadi rasional. Transisi tersebut tentunya akan memberikan energi positif pada karakter remaja yang diwujudkan dengan kemampuan untuk bersikap bijaksana dalam menggunakan teknologi dimasa kini maupun dimasa yang akan datang.
\end{abstract}

\section{Kata Kunci: Afirmasi Positif, Pendidikan Karakter, Remaja, Era Milenial}

\section{INTRODUCTION}

The development of technology has an impact, one of which is on changes in adolescent social activities which are closely related to the use of technology. Millennial adolescents are now increasingly adept at using the internet to interact with other people, who are actually more interested in doing it through social media. This pattern certainly has an impact on the formation of characters from a very different environment. not even one day a teenager does not access social media. This is reinforced by the results of research conducted by Supratman (2018) that digital native in this case the young generation or millennial who were born when the internet has become part of their lives spend $79 \%$ of their time to access the internet. Various kinds of facilities can be obtained by digital native with the facilities available on social media to meet their needs both from clothing, food and shelter. The amount of millennial generation needs on social media makes them have a very high dependency on the WIFI network so it is called a WIFI hunter. The shape of this change which in the end will bring adolescents to form their social environment as a digital environment that has been very familiar since childhood so that it has a big influence on the DOI : https://dx.doi.org/10.26486/ijagc.v1i1.1047

URL : http://ejurnal.mercubuana-yogya.ac.id/index.php/IJAGC/index

Email : ijagc@mercubuana-yogya.ac.id 
formation of character.

Koni (2016) states that in the modern era such as the current use of social networking does not function as it should have an effect on character education with the occurrence of various cases that indicate a moral crisis in the character of adolescents. Changes that occur are also associated with a decrease in learning achievement because teenagers are more interested in the digital world so they are lazy to learn. In addition, access to content that contains pornography can be easily seen and consumed by adolescents who have not been able to choose and absorb the information they get well. Indra, Dundu and Kairupan (2019) also said similar things related to the high level of internet usage which had an impact on psychological function and mental health which was vulnerable to the development of addictive behavior. The results of the study of 171 respondents involved, as many as $70.2 \%$ experienced moderate internet addiction and 32.2\% experienced depression. This condition certainly needs to get serious attention by placing the importance of organizing character education for adolescents to face various digital challenges in the millennial era as it is today.

Character is a fundamental thing that is very important and plays a role in the development of national civilization related to the stability of life, because character makes individuals have psychological endurance to survive and gives meaning to unpleasant conditions. Millennial adolescents need character education which, according to Abdul Mujib and Jusuf Mudzakkir (Harahap, 2016), is a process to internalize values through teaching, habituation, guidance, nurturing, controlling, and developing the potential to achieve harmony and perfection in life. Character education needs to be carried out continuously and continuously so as to form good attitudes and behavior in adolescents which is reflected in daily activities, because so far the education process is still criticized as a form of conveying theory and not yet fully applied to life so there is still a gap between the development of science and technology with the behavior of the younger generation. The form of character education that can be cultivated is by giving positive affirmations that can help individuals change negative thought patterns and tend to be destructive to constructive thought patterns. Sari (2013) in his research shows that self-affirmation is effective in reducing academic anxiety. The illogical mindset that is raised due to academic anxiety is very much related to psychological factors so that it can produce maladaptive behavior. Self-affirmation in this case can lead to healthy thinking so that manifested feelings and actions that are in accordance with the norm and able to provide broad insights and be able to see each problem from various points of view.

Positive affirmations are built from within the individual by focusing on self-strength more positively so that it will foster feelings and adaptive behavior. Affirmations can be in the form of short sentences that contain positive thinking patterns that affect the subconscious mind. Lack of positive self-affirmation can lead to low self-esteem as indicated by the inability or difficulty in adjusting to changes in the conditions experienced (Agustin \& Handayani, 2017). One example of a case that still often occurs in the world of education and social environment is for example a case of bullying, whether done through social media or also in the real life realm. Bullying still happens because it is considered as a natural thing even though it has a harmful impact. Marela, Wahab and Machira (2017) who examined 210 high school teenage students in Yogyakarta explained that adolescents who experience bullying are 1.5 times more likely to experience depression when compared to adolescents who do not experience bullying. Bullying predominately causes stresses that cause disturbances in psychological, physical and emotional conditions. The biggest bullying condition experienced by many teenagers is verbal bullying as much as $47 \%$ compared to other forms of bullying. The verbal bullying experience felt by respondents was in the form of taunts or calls with names that were not liked.

Some of the results of these studies are one form of the inability of individuals to 
build positive feelings within themselves through affirmations. This certainly must be realized by educators or parents who are in the closest zone for adolescents to immediately determine the steps in building habituation in character education through positive affirmations. The formation of teenage characters in the millennial era with all the challenges that exist and the exposure to problems and information that is very fast and without filter, requires intelligence to be able to analyze problems using logical thinking patterns. Positive affirmations as a matter of fact is very easy to do but not all teenagers are able to develop and apply them in their daily lives. Basically, adolescence is a period of starting to recognize themselves and explore the world outside of themselves. There is a high curiosity, so that in adolescence, behavior that is adopted directly from the social environment begins to emerge without considering whether the behavior is right or wrong. The issue of millennial generation characteristics that can be trapped in the negative impact of the globalization era due to changes in values and attitudes so that there is a shift in rational values to be irrational. The ease available because of technological advances can actually provide the potential for individuals to limit their social mobility and prefer to be busy interacting virtually through their social media. Other effects of globalization on millennial generation include promiscuity, drug abuse, smoking and free sex in adolescents. The approach that can be taken to fortify the souls of adolescents to not be easily influenced by the need for steps in character education as an effort to prevent the development of the negative influence of the globalization era.

Millennial era is certainly not only related to negative impacts. If addressed wisely, the changes and developments in this era can provide extraordinary benefits for human life. The creation of various innovations in the field of technology has proven to have an impact on the ease and value of efficiency in various fields. Therefore, this article reviews the importance of developing and forming positive affirmations for adolescent characters to form a strong mentality in facing challenges and competition in the millennial era.

\section{METHODS}

This article is a literature review, mainly from research results and also analysis of issues related to scientific references. The study provides an explanation of some of the meanings of the variables raised in this article. The type of data used by the author in this study is primary data by observing and secondary data, namely data obtained from journals, books, documentation studies, and online references. The data that has been obtained is then analyzed by descriptive analysis method. Descriptive analysis method is done by describing the facts which are then followed by the analysis, not merely describing, but also provides sufficient understanding and explanation.

\section{Meaning Of Education}

Education has a deeper meaning than teaching. Teaching is generally interpreted narrowly and formally as an activity to convey subject matter to students. The process in education is carried out through various methods with the aim of providing understanding to other people about how to behave according to needs. Education can take place informally or informally to improve knowledge, habits and attitudes in the social environment. Education is also closely related to the meaning of self-instruction, which means that education can be done independently through oneself to strengthen positive values in individuals. Education is a deliberate effort to increase the maturity of an individual so that he is able to be morally responsible and all his actions are in accordance with the prevailing norms in society.

True education does not only produce students who are able to pass tests and improve their academic achievement, but need to hone their abilities in internalizing the knowledge they have in real life. Wasitohadi (2012) developed several meaningful educational 
characteristics, namely:

A. Welfare education

Education is organized to realize prosperity by fulfilling human needs in the implementation of education that is not oppressive, and feels able to live and learn according to its ideals and be able to develop education that is oriented to the development of humanity as a whole

B. Education that respects human dignity

Meaningful education is humane education, namely education that bases itself on respect for human dignity and human rights. Therefore, humans should not be used as objects. Education aims so that students can develop as subjects in various dimensions of humanity.

C. Education for justice

Meaningful education must be an education for justice as well as an embodiment of social justice. Therefore, social justice is a permanent demand that humans fight for. Humans can only live properly as humans if their fundamental rights are fulfilled or social justice is achieved so that education is not only enjoyed by the elite.

\section{Understanding Character Education}

Character education in the context of education in Indonesia is the education of values, namely education of noble values derived from the culture of the Indonesian people themselves, in order to foster the personality of the younger generation. Character education is not just teaching what is right and what is wrong, more than that, character education instills habits (habituation) about good things so that individuals become aware (cognitive) about right and wrong, able to feel (effective) good values and used to do it (psychomotor). In other words good character education must involve not only aspects of good knowledge (moral knowing), but also feeling well or loving good (moral feeling), and good behavior (moral action). Character education emphasizes the habit or habits that are continuously practiced and carried out (Julaiha, 2014). The context of character education is actually no different from the concept of conditioning learning from Pavlov and Skinner's learning theories, meaning that in character education cannot be formed instantly, it must go through an accustomed process.

Wardani (2018) in his writings on the role of counselors in strengthening character education states that character education is the inculcation of values and norms on students to become individuals who are ready to be responsible. The value of reinforcement is implemented in the guidance and counseling service because it is in line with the philosophy of guidance and counseling, namely the counselee's independence. Character education must also involve the school, parents and other related parties. Education in this context is not only in the formal domain but also informal, where the education process is carried out continuously to strengthen the character of adolescents.

\section{Positive Affirmation}

Affirmation is a therapeutic concept of cognitive behavior by emphasizing giving instructions to self in overcoming problems more effectively. Affirmations can mean that individuals are able to accept unpleasant conditions (Kusumastuti, Iftayani \& Noviyanti, 2017). Every human being must have felt doubt, feeling lack of confidence, fear or thinking bad things that might not necessarily happen. The affirmation process is done to change negative perceptions into something that motivates to see more positive things about him. Words or sentences that are affirmative, are believed to increase positive energy. One example of a positive affirmation sentence is "I am healthy ... I certainly can". A simple affirmation form of what is said is believed to be a reality that will be accepted by the 
individual, because affirmation is needed to find one's desires and goals. Affirmations involve many processes such as thinking, listening, saying or writing a statement either for yourself or for others repeatedly (Dwipayanti \& Sutomo, 2019).

Positive affirmations have been widely used not only in the sphere of education but in the realm of health. Affirmations are used as a form of therapy to relax the mother's early pregnancy. Sukesi (2017) based on the results of her research proves that affirmation therapy can reduce the level of anxiety in pregnant women in the trimester of pregnancy. Decreased anxiety is characterized by positive acceptance and confidence in pregnant women that there is a feeling of being able and less fear that arises until the time of birth later. According to Zainiyah, Dewi and Wantiyah (2018), affirmation is a relaxation technique that provides comfort and calm because affirmation can affect the parasympathetic nervous system and sympathetic nerves to trigger endorphin hormone secretion, decrease stress levels, reduce blood pressure, slow down breathing and reduce tension in the body.

\section{Youth In The Milenial Era}

Papalia and Olds (Putro, 2017) provides an understanding that adolescence is a period of developmental transition between childhood and adulthood. During adolescence there are changes in the relationship with parents and future orientation. Currently in the process of transformation in adolescents, it is very closely related to technology and the existence of social media so that it is often referred to as millennial generation.

Millennial adolescence is considered as a time that has closeness or sensitivity to new things and is easily attracted to the development of technology or social media. Ali and Purwandi (Walidah, 2017) Summed up 3 characteristics of adolescents in the millennial era namely connect, creative and confidence. The definition of connect in question is that the millennial generation as a person who is good at socializing primarily to the community on social media. Then, creative is the meaning that this generation is able to think out of the box, have ideas, ideas. Confidence that has a confident character, dare to express opinions and not hesitate to express opinions especially on social media. Some of these characteristics can certainly be interpreted as great opportunities, because many millennial youth are already involved in business and are able to open up job opportunities. However, in its development, the thing that needs to be understood is that these positive characteristics must be accompanied by strength of character so as to form a directed attitude and in accordance with the norm.

Change in life can be understood as a natural thing to happen. Change will have positive and negative impacts that are closely related to the mindset and response to these changes. Millennial era is identical with the era of freedom in getting information through social media and quickly responding to existing stimulus. In this millennial period, adolescents tend to like to show their existence through unique and impulsive ways. Nurhaini (2018) in his research mentioned that the millennial era that experienced very rapid development brought changes in adolescents to follow the trend so that they tended to behave consumptively because they wanted to make themselves look better than others. The behavior exhibited tends to be impulsive by purchasing products based solely on desire without further considering the benefits of the product. This behavior is one example of the problems experienced by millennial adolescents today. A big desire not balanced with a healthy mindset will produce many problems. Some cases involving adolescents, the majority occur due to errors of thought patterns that result in teens showing wrong behavior. Ardiansyah, et al (2017) also highlighted the problems experienced by millennial adolescents who are closely related to gadgets and complacent about the conveniences offered so they tend to show symptoms of addiction and lead to the classification of FOMO (Fear of Missing Out) disorders, which means there is a fear of losing interaction with his community through 
cyberspace. Indications of this disorder can cause stress, alienation from real social life, moral change and character. This form of behavior certainly cannot be left alone, there needs to be an action that starts from oneself to avoid the negative effects of the development of the globalization era.

One approach that can be done by developing self-talk in the form of positive affirmations to strengthen the character of adolescents in the millennial era. Positive affirmations can be done easily and must be cultivated, because affirmations are statements in the form of positive sentences to strengthen yourself in the face of various competitions and challenges. Sherman and Cohen (2006) states that affirmations are self-systems that shape self-image, self-integrity and moral development and adaptability. Individuals who are able to give affirmations to themselves are considered to have the confidence to be able to face threats, and adapt to negative information. Affirmations as a form of coping with uncomfortable conditions so that it becomes motivation in life.

If you look back at the potential possessed by teenagers today, certainly many positive things that can be developed. Especially when associated with technological developments that are very rapid. The potential and development can be in line with the strength of character as a basic capital for adolescents to behave and behave. Positive affirmation is one step that must be initiated and habituated to create the character of a wise and polite millennial generation in social life, both in cyberspace or in the real environment that can be done in formal or informal education.

\section{CONCLUSION}

Every true human being cannot predict what will be experienced or confronted in the future, but humans are able to learn and use all the potential they have to become a useful person for their own lives and social environment. Similarly, a teenager who has extraordinary energy in showing its existence, by doing various forms of behavior that leads to positive or negative actions. This happens certainly can't be separated from the influence of the external environment and the mindset of adolescents themselves. The ease and breadth of information presented makes teenagers fall asleep and get caught up in wrong behavior. Therefore, adolescents need to get character education through therapy that can be done by themselves by applying affirmations in the form of positive words or sentences that will affect psychic development so that they have the ability to control themselves when they are in difficult times.

\section{REFERENCES}

Adriansyah, M. A., Munawarah, R., Aini, N., Purwati, P., \& Muhliansyah. (2017). pendekatan transpersonal sebagai tindakan preventif "domino effect" dari gejala fomo (fear of missing out). Psikostudia: Jurnal Psikologi, 6(1), 33-40

Agustin, I. M., \& Handayani, S. (2017). Case report: Afirmasi positif pada harga diri rendah situasional pasien fraktur femur. Jurnal Ilmiah Kesehatan Keperawatan, 13(2).

Dwipayanti, P. I., \& Sutomo. (2019). Pengaruh pemberian intervensi reimprinting pada perubahan kadar kolesterol. Jurnal Keperawatan, 12(1), 1-15

Harahap, A. M. (2016). Konsep dan strategi pendidikan karakter di sekolah. Jurnal Darul 'Ilmi, 4(1). 
Indra, C. M., Dundu, A. E., \& Kairupan, B. R. (2019). Hubungan kecanduan internet dengan depresi pada pelajar kelas XI di SMA Negeri 9 Binsus Manado tahun ajaran 2018/2019. Jurnal Medik dan Rehabilitasi (JMR), 1(3).

Julaiha, S. (2014). Implementasi pendidikan karakter dalam pembelajaran. Dinamika Ilmu, $14(2)$.

Koni, S. M. (2016). Pengaruh jejaring sosial terhadap pendidikan karakter peserta didik.. Jurnal Manajemen Pendidikan Islam, 4(2).

Kusumastuti, W., Iftayani, I., \& Noviyanti, E. (2017). Efektivitas afirmasi positif dan stabilisasi dzikir vibrasi sebagai media terapi psikologis untuk mengatasi kecemasan pada komunitas pasien hemodialisa. Tarbiyatuna, 8(2), 123-131.

Marela, G., Wahab, A., \& Marchira, C. R. (2017). Bullying verbal menyebabkan depresi remaja SMA Kota Yogyakarta. Berita Kedokteran Masyarakat, 33(1), 43-48

Mustofa, Bisri. (2015). Psikologi pendidikan. pendekatan, orientasi dan perspektif baru sebagai landasan pengembangan strategi dan proses pembelajaran (teori dan praktik). Dua Satria Offset.

Nurhaini, D. (2018). Pengaruh konsep diri dan kontrol diri dengan perilaku konsumtif terhadap gadget gadget remaja SMA N 1 Tanah Grogot. PSIKOBORNEO, 6(1).

Putro, K. Z. (2017). Memahami ciri dan tugas perkembangan masa remaja. Jurnal Aplikasi Ilmu-ilmu Agama, 17(1).

Sari, E. N. (2013). Bimbingan mereduksi kecemasan akademik peserta didik melalui teknik self affirmation (penelitian pra-eksperimen terhadap peserta didik Kelas X SMA LabSchool UPI Bandung Tahun Ajaran 2011/2012). Jurnal Antologi UPI, 1(1).

Sherman, K. D., \& Cohen, G. L. (2006). The psychology of self-defense: Self-affirmation theory. Advances In Experimental Social Psychology, 38.

Sukesi, N., \& Husada, N. W. (2017). The effectiveness of affirmation relaxation therapy towards anxiety in pregnant mothers on third trimester in facing labor. Advances in Health Sciences Research, 3.

Supratman, L. P. (2018). Penggunaan media sosial oleh digital native. Jurnal Ilmu Komunikasi, 15(1).

Walidah, A. I. (2017). Tabayyun di era generasi millennial. Jurnal Living Hadis, 2(1).

Wardani, S. Y. (2018). Peranan konselor dalam penguatan pendidikan karakter. prosiding seminar nasional pendidikan.

Wasitohadi. (2012). Mengembangkan pendidikan bermakna di indonesia dan implikasiimplikasinya. Satya Widya, 28(1). 
Zainiyah, R., Dewi, E. I., \& Wantiyah. (2018). Pengaruh teknik relaksasi afirmasi terhadap stres mahasiswa yang menempuh skripsi di program studi ilmu keperawatan universitas Jember. e-Jurnal Pustaka Kesehatan, 6(2). 